\title{
Suitability of Jatropha curcas L. as Source of Oil and Biodiesel Production in Benue State in Nigeria Akogwu RD ${ }^{1}$, Aguoru $\mathrm{CU}^{2}$, Ikpa F³ , Ogbonna $\mathrm{I}^{4}$ and Olasan $\mathrm{JO}^{2}$
}

${ }^{1}$ Department of Biological Sciences, Environmental Science and Renewable Energy Unit, University of Agriculture, Makurdi, Nigeria ${ }^{2}$ Department of Biological Sciences, Plant Science and Biotechnology Unit, University of Agriculture, Makurdi, Nigeria ${ }^{3}$ Department of Biological Sciences, Zoology Unit, University of Agriculture, Makurdi, Nigeria

${ }^{4}$ Department of Biological Sciences, Industrial Microbiology and Biotechnology Unit, University of Agriculture, Makurdi, Nigeria

\begin{abstract}
The present study investigated the suitability, efficiency and sustainability of biodiesel production in Benue State, Nigeria, using Jatropha curcas $L$. seeds as feedstock. The emission rate of Jatropha biodiesel and petroleum diesel was also compared. Seeds were collected from the three Senatorial zones of Benue State. Three Local Government Areas from each zone were targeted. A total of $9 \mathrm{~kg}$ of seeds was processed and investigated per zone. Processing include: drying, shelling, pre-heating and oil extraction. Oil was extracted at the National Research Institute for Chemical Technology (NARICT) Zaria, Nigeria. Further oil extraction and trans-esterification were carried out in the Laboratory of Chemical and Biological Engineering, University at Buffalo, New York, USA. Zone A, B and C produced $985 \mathrm{ml}, 980 \mathrm{ml}$ and $975 \mathrm{ml}$ of oil respectively from $3 \mathrm{~kg}$ of Jatropha seeds. Seeds combined from the three zones yielded $1000 \mathrm{ml}$ of oil and $1000 \mathrm{ml}$ of biodiesel per $3 \mathrm{~kg}$ of seed. Quantity of oil is not associated with zones of collection $\left(x^{2}=0.263, p=0.67\right)$. Also, no association exists between zones and quantity of biodiesel $\left(x^{2}=0.003\right.$, $p=1.00)$. Jatropha diesel $(500 \mathrm{ml})$ was consumed in 18 minutes and produced lighter smoke while petroleum diesel was consumed in 15 minutes and produced thicker smoke. The amount of carbon-monoxide emitted by petroleum diesel was twice the emission of Jatropha diesel. Therefore, sufficient quantity of biodiesel was obtained from Jatropha seed for domestic, industrial and automobile use. Jatropha diesel in the present finding was more efficient and economical when compared with petroleum diesel. From this report, Jatropha curcas is a perfect candidate as a source of obtaining cheap and safer renewable energy in line with UN goal 13 on climate action. Moreover, Jatropha curcas plant is easily cultivated under minimal edaphic and climatic requirement. However, advanced technology and technical know-how is required in biodiesel processing from Jatropha seed for maximum output.
\end{abstract}

Keywords: Biodiesel; Environment; Jatropha curcas; Oil; Renewable energy

\section{Introduction}

Hydrocarbon In the twenty-first century, the level of atmospheric carbon dioxide is $30 \%$ higher than the pre-industrial era [1] sharing a straight relationship with the hike in fossil fuel burning since 1950. In 2011, the global transport sector had a $28 \%$ energy share and accounted for almost a quarter of the world's carbon dioxide emissions as per US Energy Information Administration in 2012. Carbon dioxide is the main greenhouse gas contributing to global warming [2]. The irony of the situation is that mankind is exploiting a decreasing global oil reserve at the expense of the environment and that has been causing energy improbability and climate catastrophes. Biodiesel is the definitive solution for replacing the petroleum-centered transports industry [3]. In addition to its superior energy currency than bioethanol; it also kowtows to the existing diesel engines. However, the biofuel industry is being subjected to controversies including food insecurity due to the discrepancy of staple crops which are being used for biofuel production [4]. Choosing a proper feedstock is very significant; lipids acquired from non-edible feedstock are trendy because they do not contend with the food market. Also, the exorbitant cost of edible oils prevents their use in Biodiesel preparation. This is why non-edible oils are affordable for Biodiesel production [5].

The use of Jatropha curcas $L$, a non-edible crop able to adapt to marginal soils and semiarid climates appears to be a promising alternative for the production of biodiesel in tropical and subtropical regions. Native to Central America, Jatropha curcas $L$ is a small tree in the Euphorbiaceae family which is found in all the tropical and subtropical zones [6]. The plant is monoecious and flowers are unisexual; occasionally hermaphroditic flowers occur; 10 stamens arranged in 2 distinct whorls of 5 each in a single column in the androecium and in close proximity to each other. In the gynaecium, the 3 slender styles are connate to about $2 / 3$ of their length, dilating to a massive bifurcate stigma. Female flowers with sepals up to $18 \mathrm{~mm}$ long, persistent; ovary 3-locular, ellipsoid, 1.5-2 mm in diameter, style bifid. Fruit an ellipsoid capsule $2.5-3 \mathrm{~cm}$ long, $2-3 \mathrm{~cm}$ in diameter, yellow, turning black. Seeds black, 2 per cell, ellipsoid, triangular-convex, $1.5-2 \times 1-1.1 \mathrm{~cm}$.

The non-edible seeds containing between $28 \%$ and $38 \%$ oil, which may be transformed into Jatropha methyl ester (JME), a good quality biodiesel [7]. Though Jatropha curcas L grows naturally in Africa, its cultivation on an industrial scale is a very recent business enterprise for which little reliable scientific data exists either for management or environmental assessment. Jatropha curcas $L$. is made popular as unique candidate among renewable energy sources due its peculiar features like speedy growth, drought forbearance and easy propagation, higher oil content than other oil crops, small gestation period, wide range of

"Corresponding author: Olasan JO, Department of Biological Sciences, Plant Science and Biotechnology Unit, University of Agriculture, Makurdi, Nigeria, Tel: +234 8067691526; E-mail: lekanolasan@yahoo.com

Received August 22, 2018; Accepted September 06, 2018; Published September 30,2018

Citation: Akogwu RD, Aguoru CU, Ikpa F, Ogbonna I, Olasan JO (2018) Suitability of Jatropha curcas L. as Source of Oil and Biodiesel Production in Benue State in Nigeria. J Pet Environ Biotechnol 9: 378. doi: 10.4172/2157-7463.1000378

Copyright: @ 2018 Akogwu RD, et al. This is an open-access article distributed under the terms of the Creative Commons Attribution License, which permits unrestricted use, distribution, and reproduction in any medium, provided the original author and source are credited. 
environmental adaptation, the optimum plant size and structure [8]. Based on these interesting properties, potentials and hyped claims on Jatropha curcas $L$, a lot of investors, policy makers and clean development mechanism project developers are interested in Jatropha curcas $L$ to tackle the challenges of energy supply and Green House Gas (GHG) emission reduction [9]. The cost of bio-diesel is the most important aspect of promotion of Jatropha curcas $L$ for bio-diesel production, being eco-friendly, easy to produce raw material, easy oil extraction and transesterification. This gives a current awareness of Jatropha curcas $L$ as multifunctional role for eco-environmental benefits and simultaneous wasteland reclamation, carbon sequestration, biodiesel production and employment generation. This research focused on the suitability, efficiency and sustainability of Jatropha curcas as feedstock for biodiesel production in Benue State, Nigeria. The plant is available in all the Local Government Areas of the state; they grow in the wild and can be easily cultivated. Many locals in the rural communities use it as fence to prevent predators from their farms and homes where they reside.

\section{Materials and Methods}

\section{Seed procurement}

Seeds of Jatropha curcas $L$ were collected across 9 Local Government Areas in three senatorial districts/zones of Benue State Nigeria. A total of $9 \mathrm{~kg}$ of seeds was collected from each zone. Details of seeds collection are given in Table 1 . Seeds collected from each zone were thoroughly mixed, sundried and stored.

\section{Extraction of Jatropha curcas oil from seeds (single zones)}

Procedures adopted by Subroto et al. were used. Four kilograms (4 $\mathrm{kg}$ ) out of the nine kilograms $(9 \mathrm{~kg})$ seeds collected from each zone was taken to National Research Institute for Chemical Technology (NARICT) Basawa road Zaria Kaduna State Nigeria. Seeds (3 kg) were de-hulled with the use of a locally fabricated machine. The chaff was separated from the inner seeds by manual winnowing and set aside. The seeds were milled using the fabricated processing mill and crushed to fine smaller particles. The fine particles were preheated and the oil extracted with the use of a locally fabricated press machine which expelled the oil following the methods of Akogwu [10]. Total oil extracted from each zone was measured using a conical flask and stored in a well labeled air tight plastic bottle.

\section{Extraction of Jatropha curcas oil from seeds (combined zones)}

One kilogram $(1 \mathrm{~kg})$ each of the seeds set aside from zones $\mathrm{A}, \mathrm{B}$ and $\mathrm{C}$ was properly mixed together to serve as a complete set of seeds representing the entire Benue State. The seeds after mixing were weighed to confirm it is three kilogram $(3 \mathrm{~kg})$. Seeds were dehulled, milled and pre-heated for oil extraction as stated above. Quantity of oil extracted in the combined zone analysis was determined and stored.

\section{Processing of Jatropha curcas oil}

Oil processing was done at the National Research Institute for Chemical Technology (NARICT) Basawa road Zaria Kaduna State Nigeria. Oil was reacted with methanol to reduce free fatty acid using $\mathrm{H}_{2} \mathrm{SO}_{4}$ for the pre-treatment. $\mathrm{KOH}$ was used as an alkaline catalyst for the transesterification reaction. This reaction was carried out with 6:1 molar ratio of $\mathrm{KOH}$ to the pre-treated Jatropha oil. The amount of $\mathrm{KOH}$ used as catalyst was based on the amount needed to neutralize the unreacted acids [11]. The reaction was carried out for half an hour and the products were allowed to settle overnight before removing the glycerol layer from the bottom in a separating funnel to get the ester layer on the top, called biodiesel. Quantity of biodiesel produced from known volume of processed oil of each zone was measured.

\section{Advanced methods of oil extraction and processing}

For quality assurance and optimal yield, oil was further extracted and processed from Jatropha curcas seeds collected from each zone. This stage was done at the Department of Chemical and Biological Engineering, University at Buffalo, New York, USA. The seeds were dried in the oven for 20 minutes at $65^{\circ} \mathrm{C}$ to reduce the moisture content [5]. The seeds were de-hulled with a shelling machine manufactured by Thailand National Metal and Materials Technology Centre which separated the seeds from the husk. The milled seeds were then poured into an advanced oil extracting machine. Volumes of oil produced were measured. Oil processing and transesterification followed the methods of Farouk et al. [11]. The volumes of biodiesel produced were also measured.

\section{Testing for efficiency of the biodiesel produced from Benue state}

Biodiesel $(500 \mathrm{ml})$ was measured and injected into a fuel filter of a diesel engine generating set. The same quantity of fossil fuel diesel was also filled in another filter connected to the generating set and turned on in an enclosed compartment with a carbon monoxide (CO) detector alarm. The generator was turned on. The quality of emission was observed. A stop watch was used to monitor the timing for complete combustion of each fuel type.

\section{Results and Discussion}

Table 2 presents the quantity of oil and biodiesel produced from 3 $\mathrm{kg}$ of Jatropha curcas seed. Zone A yielded $885 \mathrm{ml}$ of oil and $880 \mathrm{ml}$ of biodiesel. Zone B produced $882 \mathrm{ml}$ of oil and $880 \mathrm{ml}$ biodiesel. Zone C produced $881 \mathrm{ml}$ of oil and $878 \mathrm{ml}$ of biodiesel. Maximum volume of oil was obtained from seeds of Zone A ( $885 \mathrm{ml})$. The minimum oil ( 881 $\mathrm{ml}$ ) obtained from Zone $\mathrm{C}$ produced the minimum biodiesel ouput $(878 \mathrm{ml})$. On the average, the three zones yielded $882.67 \pm 1.2$ oil and $879 \pm 0.67$ biodiesel. Seeds combined from all zones yielded the highest volume of oil recorded $(900 \mathrm{ml})$ which gave rise to $880 \mathrm{ml}$ of biodiesel. Statistically, oil and biodiesel output is not associated with locations ( $\mathrm{p}>0.05)$.

Advanced technology contributed more to oil and biodiesel production than the inferior machineries. However, results from both methods are consistent. From Table 3, Zone A produced the highest volume of oil $(985 \mathrm{ml})$ while zone $\mathrm{C}$ recorded the minimum $(975 \mathrm{ml})$. As a result, Zone A yielded the maximum biodiesel production of 982 $\mathrm{ml} / 3 \mathrm{~kg}$ seed followed by zone B $980 \mathrm{ml} / 3 \mathrm{~kg}$ seed. Under the advanced technological approach, the combined zones yielded $1000 \mathrm{ml}$ of oil and $1000 \mathrm{ml}$ of biodiesel. These represent the optimized quantity of oil and biodiesel produced from Benue State, Nigeria.

Qualitative assessment of Jatropha biodiesel showed more efficiency than petroleum diesel (Table 4). Jatropha Diesel generated lighter smoke with pleasant smell. It had low amount of black particulate matter, therefore not dusty. These attributes confirm its environmental friendliness. However, petroleum diesel produced thicker smoke with high amount of dusty black particulate matters that emitted pungent smell. From quantitative assessment (Figure 1), Jatropha diesel completed its combustion in a long period (18 minutes) with inconsequential carbon monoxide alarm trigger. Meanwhile, petroleum diesel completed its combustion within 15-16 minutes that quickly triggered the carbon monoxide alarm clock. 
Citation: Akogwu RD, Aguoru CU, Ikpa F, Ogbonna I, Olasan JO (2018) Suitability of Jatropha curcas L. as Source of Oil and Biodiesel Production in Benue State in Nigeria. J Pet Environ Biotechnol 9: 378. doi: 10.4172/2157-7463.1000378

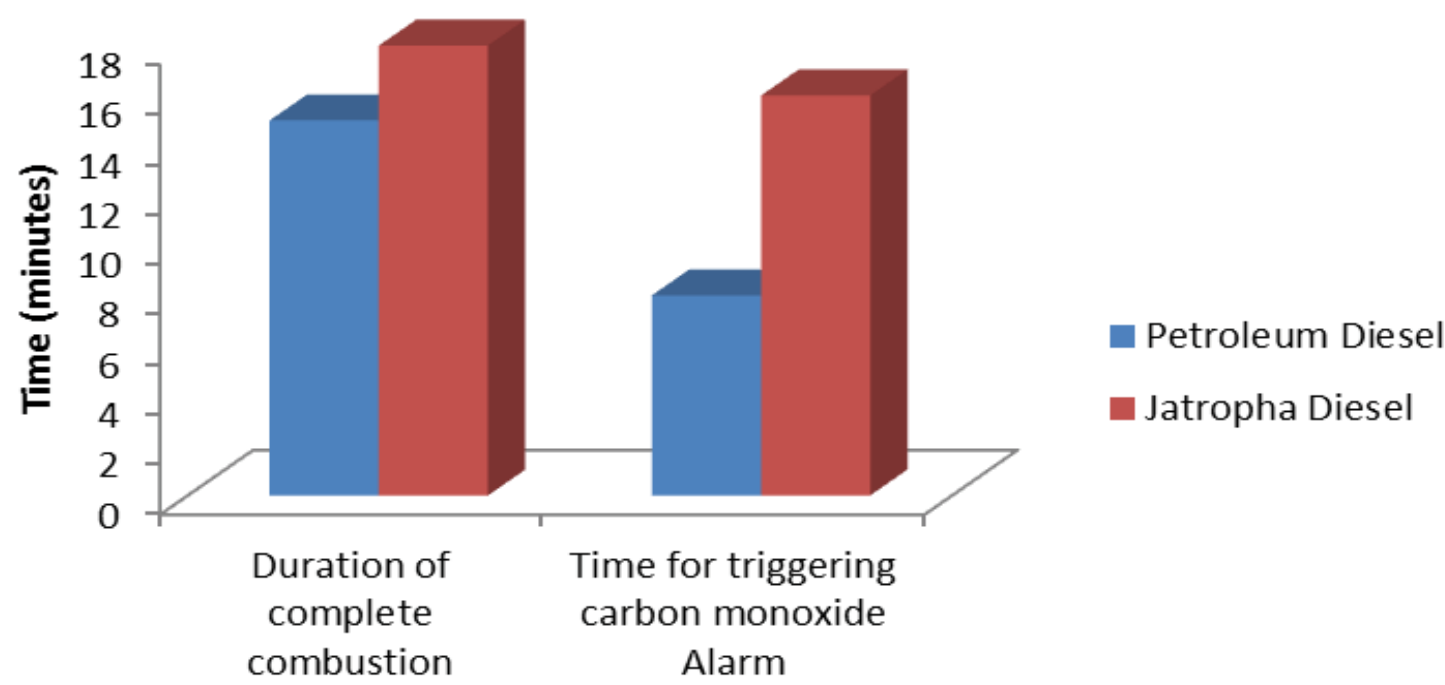

\section{Quality Parameters}

Figure 1: Quantitative assesment of Jatropha curcas biodiesel efficiency.

\begin{tabular}{|c|c|c|c|}
\hline Zone Code & Local Government Areas & Location & Quantity (kg) \\
\hline \multirow{3}{*}{ Zone A Senatorial District } & Konshisha & Tse-Agbaragba & $3 \mathrm{~kg}$ \\
\hline & Katsina-Ala & Katsina-Ala & $3 \mathrm{~kg}$ \\
\hline & Ukum & Sankera & $3 \mathrm{~kg}$ \\
\hline \multicolumn{3}{|c|}{ Total } & $9 \mathrm{~kg}$ \\
\hline \multirow{3}{*}{ Zone B Senatorial District } & Makurdi & Makurdi & $3 \mathrm{~kg}$ \\
\hline & Buruku & Buruku & $3 \mathrm{~kg}$ \\
\hline & Gboko & Gboko & $3 \mathrm{~kg}$ \\
\hline \multicolumn{3}{|c|}{ Total } & $9 \mathrm{~kg}$ \\
\hline \multirow{3}{*}{ Zone C Senatorial District } & Otukpo & Otukpo & $3 \mathrm{~kg}$ \\
\hline & Oju & Oju & $3 \mathrm{~kg}$ \\
\hline & Ogbadibo & Orokam & $3 \mathrm{~kg}$ \\
\hline \multicolumn{3}{|c|}{ Total } & $9 \mathrm{~kg}$ \\
\hline
\end{tabular}

Table 1: Collection of Jatropha curcas seeds across locations in three senatorial districts of Benue state.

\begin{tabular}{|c|c|c|c|}
\hline Zones & Seed Weight $(\mathrm{kg}) / \mathrm{Input}$ & Oil Quantity (ml)/Output & 885 \\
\hline $\mathrm{A}$ & 3 & 882 & 881 \\
\hline $\mathrm{B}$ & 3 & 880 \\
\hline $\mathrm{C}$ & 3 & $882.67 \pm 1.2$ \\
\hline Mean & -- & 0.24 \\
\hline CV & -- & 900 \\
\hline Combined Zones & 3 & $879 \pm 0.67$ \\
\hline X2 (Zone and Oil Quantity) $=0.263, \mathrm{p}=0.67$ (No association, $\mathrm{p}>0.05)$ & \\
\hline X2 (Zone and Biodiesel Quantity) $=0.003, p=1.00$ (No association, $\mathrm{p}>0.05$ & \\
\hline
\end{tabular}

Table 2: Quantity of oil and biodiesel produced from Jatropha curcas seed.

\begin{tabular}{|c|c|c|c|}
\hline Zones & Seed Weight $(\mathrm{kg}) / \mathrm{Input}$ & Oil Quantity (ml)/Output & Biodiesel Quantity (ml)/Output \\
\hline A & 3 & 985 \\
\hline B & 3 & 980 \\
\hline C & 3 & 975 \\
\hline Mean & - & $980 \pm 2.89$ \\
\hline CV & -- & 0.51 \\
\hline Combined Zones & 3 & 1000 \\
\hline $\begin{array}{l}\text { X2 (Zone and Oil Quantity) }=0.355, p=0.949 \text { (No association, } p>0.05 \\
\text { X2 (Zone and Biodiesel Quantity) }=0.476, p=0.924 \text { (No association, } p>0.05)\end{array}$ \\
\hline
\end{tabular}

Table 3: Quantity of oil and biodiesel produced from Jatropha curcas seed (Advanced technology). 
Citation: Akogwu RD, Aguoru CU, Ikpa F, Ogbonna I, Olasan JO (2018) Suitability of Jatropha curcas L. as Source of Oil and Biodiesel Production in Benue State in Nigeria. J Pet Environ Biotechnol 9: 378. doi: 10.4172/2157-7463.1000378

Page 4 of 5

\begin{tabular}{|c|c|c|c|}
\hline C & Qualitative Assessment of Emission & Odour & Associated materials \\
\hline Petroleum Diesel & Thicker smoke & Pungent & High amount of black particulate matters/Dusty \\
\hline Jatropha Diesel & Lighter smoke & Not pungent & $\begin{array}{c}\text { Low amount of black particulate matters/Not } \\
\text { dusty }\end{array}$ \\
\hline
\end{tabular}

Table 4: Qualitative assessment of Jatropha curcas biodiesel efficiency.

This research has successfully produced efficient and voluminous biodiesel from Jatropha curcas seeds in Benue State Nigeria. The extraction of oil was done from the seeds obtained from various parts of the State which cuts across major representative villages and settlements in each of the Senatorial zones. The quantities of oil and diesel obtained from the three different Senatorial districts of Benue State are very encouraging. The values are higher than previous reports on Jatropha seeds from many countries. In India for instance, about $3.5 \mathrm{~kg}$ of Jatropha seed is required to obtain $1000 \mathrm{ml}$ of biodiesel [12,13]. From this work, $3 \mathrm{~kg}$ seeds produce $1000 \mathrm{ml}$ of biodiesel. Then the seeds are of high quality and one of the best types in the world. This also shows that Benue State is a good location to cultivate and commercialize Jatropha curcas as a source of renewable and efficient energy. It is possible that the soil, climate and other associated biotic/abiotic factors in Benue State are favourable to the Jaropha plant present leading to good yield in oil which is trans-esterified into diesel. This aligns with the view of Olasan et al. [14] who reported close association between groundnut yield and ecological factors.

As United Nations mandated all countries to reduce fossil fuel emission by 2020 , many countries have started seeking alternative energy source for full compliance. However, a major possible limitation to oil and diesel production from Jatropha lies in the availability of modern machines, equipment and level of technical operations. For instance, using the same $3 \mathrm{~kg}$ of seed the extraction was done under different levels of technologies yielded different results. In the shelling and separation of seeds and husk done manually, some seeds were lost in the process. However, the use of sophisticated machine separated the husk and the seeds at the time of shelling, hence there was no seed lost due to winnowing as in the manual method. The above point supports many literatures on biodiesel production from algae, waste oil and other sources that the quantity and quality of the product depends on the efficiency of technical inputs [15]. Jatropha curcas when compared with algae as a source of biodiesel production have the same function as biological sources of renewable energy. However, Jatropha plant can be grown anywhere with little support of the soil [16] as compared with algae that must be grown in water bodies or swampy areas. In terms of availability, ease of cultivation and requirements for cultivation, Jatropha plant is better than algal sources [17].

In the present findings, the efficiency of the biodiesel produced was investigated qualitatively and quantitatively by comparing it with fossil fuel under the same condition. It took 15 minutes for the fossil fuel to get used up. The same process was repeated for the biodiesel and it took 18 minutes for the diesel to get used up without any hitch of the machine going off or having a disrupted working time. This proves that the biodiesel produced from the seeds of Jatropha curcas from Benue State is more efficient and economical than petroleum diesel when processed. This finding supports popular view among scientists that biological sources are more economical in use than the chemical sources of energy $[17,18]$.

From the emission test, petroleum sources emitted twice amount of carbon monoxide with dusty particulates matter than biodiesel. This report supports previous studies done on the need to adopt biological sources as sources of pollution free energy [18]. Scientists across the globe are advocating for this type of energy to save the biosphere from pollution, health hazards and loss of biodiversity associated with the risks of fossil fuel combustion [18].

\section{Conclusion}

Benue State is recommended as a good location for maximum biodiesel production using Jatropha curcas. Fallow, underutilized and wasteful lands across the state may be utilized for this purpose. Well-equipped biorefineries should be established. This will provide job opportunities and boost the economy of the state. Jatropha is a better source of biodiesel than other biological sources considering the availability of the plant and ease of cultivation. If properly harnessed, the plant is suitable, economical, environmentally friendly and relatively cheaper source of renewable energy than fossil fuel. Hence it is recommended as a possible replacement in line with UN goal 13 on climate action. Further studies may be done on Jatropha curcas to know if there are different varieties and if differences exist in their biodiesel production.

\section{References}

1. Lindemann SR, Bernstein HC, Song HS, Fredrickson JK, Fields MW, et al (2016) Engineering microbial consortia for controllable outputs. The ISME journal 10: 2077

2. Su Y, Zhang P, Su Y (2015) An overview of biofuels policies and industrialization in the major biofuel producing countries. Renew Sust Energ Rev 50: 991-1003.

3. Ajala OE, Aberuagba F, Odetoye TE, Ajala AM (2015) Biodiesel: Sustainable energy replacement to petroleum-based diesel fuel-A review. Chem Bio Eng Rev 2: 145-156.

4. Nanda S, Azargohar R, Dalai AK, Kozinski JA (2015) An assessment on the sustainability of lignocellulosic biomass for biorefining. Renew Sust Energ Rev 50: 925-941.

5. Mardhiah HH, Ong HC, Masjuki H, Lim S, Lee H (2017) A review on latest developments and future prospects of heterogeneous catalyst in biodiesel production from non-edible oils. Renew Sust Energ Rev 67: 1225: 1236.

6. Jongschaap RE, De Vos C, Jongsma MA (2018) Feasibility study plan extracts in Rwanda: Wageningen Research Foundation (WR) Business Unit. Agrosystems Research.

7. Edrisi SA, Dubey RK, Tripathi V, Bakshi M, Srivastava P, et al. (2015) Jatropha curcas L: A crucified plant waiting for resurgence. Renew Sust Energ Rev 41: 855: 862.

8. King AJ, Montes LR, Clarke JG, Itzep J, Perez CA, et al. (2015) Identification of QTL markers contributing to plant growth, oil yield and fatty acid composition in the oilseed crop Jatropha curcas L. Biotechnol Biofuels 8: 160.

9. Rathore D, Nizami AS, Singh A, Pant D (2016) Key issues in estimating energy and greenhouse gas savings of biofuels: challenges and perspectives. Biofuel Res J 3: 380-393.

10. Akogwu RD (2011) The viability of biodiesel production in Nigeria using Jatropha curcas as a feedstock. Thesis. Department of Energy and Environmental Management. University of Abertay Dundee UK.

11. Farouk H, Zahraee SM, Atabani A, Mohd Jaafar MN, Alhassan FH (2017) Optimization of the esterification process of crude Jatropha oil (CJO) containing high levels of free fatty acids: A Malaysian case study. Biofuels 1: 8 .

12. Sharma M, Kumar A (2018) Promising biomass materials for biofuels in India's context. Mater Lett 220: 175-177. 
Citation: Akogwu RD, Aguoru CU, Ikpa F, Ogbonna I, Olasan JO (2018) Suitability of Jatropha curcas L. as Source of Oil and Biodiesel Production in Benue State in Nigeria. J Pet Environ Biotechnol 9: 378. doi: 10.4172/2157-7463.1000378

Page 5 of 5

13. Kamel DA, Farag HA, Amin NK, Zatout AA, Ali RM (2018) Smart utilization of Jatropha (Jatropha curcas Linnaeus) seeds for biodiesel production: Optimization and mechanism. Ind Crops Prod 111: 407-413.

14. Olasan JO, Aguoru CU, Omoigui LO, Ekefan EJ (2018) Character association studies in groundnut (Arachis hypogaea L). Am J Plant Sci 9: 1531-1543.

15. Doumax-Tagliavini V, Sarasa C (2018) Looking towards policies supporting biofuels and technological change: Evidence from France. Renew Sust Energ Rev 94: 430-439.
16. Ouattara B, Diédhiou I, Belko N, Cisse N (2018) Growth and transpiration of Jatropha curcas $L$. seedlings under natural atmospheric vapour pressure deficit and progressive soil drying in semi-arid climate. Agric Sci 9: 639-654.

17. Aguoru CU, Okibe PO (2015) Content and composition of lipid produced by Chlorella vulgaris for biodiesel production. Adv Life Sci Tech 36: 96-100.

18. Aguoru CU, Azua ET, Olasan OJ (2015) Approaches to minimizing and overcoming current biodiversity loss. Br J Environ Sci 3: 12-26. 